\title{
CSF Myelin Basic Protein Levels in Acute Optic Neuritis and Multiple Sclerosis
}

\author{
K.G. Warren, Ingrid Catz, and T.A. McPherson
}

SUMMARY: Normal CSF-MBP levels as determined by a RIA were $<6.2 \mathrm{ng} / \mathrm{ml} \mathrm{CSF} \mathrm{(mean} 3.9$ ). Eighty percent of patients with acute optic neuritis have CSF-MBP levels greater than $6.2 \mathrm{ng} / \mathrm{ml}$ (mean $7.6 \mathrm{ng} / \mathrm{ml} \mathrm{CSF}$ ). Five of 7 patients with acute internuclear ophthalmoplegia due to an initial exacerbation of demyelination have CSF-MBP levels above $6.2 \mathrm{ng} / \mathrm{ml}(\mathrm{mean} 6.8 \mathrm{ng} / \mathrm{ml})$. Fifty percent of MS patients with chronic progressive disease have CSF-MBP levels above $6.2 \mathrm{ng} / \mathrm{ml}(\mathrm{mean} 6.7 \mathrm{ng} / \mathrm{ml})$. MS patients experiencing monosymptomatic exacerbations show elevated CSF-MBP levels in $75 \%$ of cases (mean $8.2 \mathrm{ng} / \mathrm{ml}$ ). MS patients experiencing polysymptomatic exacerbations show significantly higher levels of CSF-MBP (mean $22.3 \mathrm{ng} / \mathrm{ml}$ ) than the patients with monosymptomatic exacerbations. Ninety-five percent of MS patients experiencing polysymptomatic exacerbations have elevated levels of CSF-MBP.

RÉSUMÉ: Les taux de protéine basique de la myéline (MBP) dans le liquide céphalo-rachidien (LCR) mesurés par radioimmunoassay (RIA) sont normalement inférieurs à $6.2 \mathrm{ng} / \mathrm{ml}$ de LCR (moyenne: 3.9 ). Quatre-vingt pour cent des malades souffrant de névrite optique aigüe ont des taux de MBP dans le LCR supérieurs à $6.2 \mathrm{mg} / \mathrm{ml}$ (moyenne $7.6 \mathrm{ng} / \mathrm{ml}$ ). Cinq malades sur sept souffrant d'ophtalmoplégie internucléaire aigüe secondaire à une poussée de démyélinisation ont des taux de MBP dans le LCR supérieurs à $6.2 \mathrm{ng} / \mathrm{ml}$ (moyenne $6.8 \mathrm{ng} / \mathrm{ml}$ ). Cinquante pour cent des malades atteints de sclérose en plaques chronique et progressive ont des taux de MBP/LCR supérieurs à $6.2 \mathrm{ng} / \mathrm{ml}$ (moyenne $6.7 \mathrm{ng} / \mathrm{ml}$ ). $75 \%$ des malades dont les poussées se traduisent par un seul symptôme ont des taux de MBP/LCR anormalement élevés (moyenne $8.2 \mathrm{ng} / \mathrm{ml}$ ) alors que $95 \%$ de ceux dont les poussées impliquent plusieurs symptômes démontrent des taux encore plus élevés (moyenne $22.3 \mathrm{ng} / \mathrm{ml}$ ).

Les taux de MBP/LCR sont donc utiles pour évaluer l'activité de la maladie et l'efficacité de la thérapeutique.

Can. J. Neurol. Sci. 1983; 10:235-238

Multiple sclerosis (MS) patients usually show abnormalities in cerebrospinal fluid (CSF). More than five mononuclear leukocytes per cubic millimeter are found in $50 \%$ of cases, total protein (TP) is increased above normal (.45 grams/liter) in $66 \%$ of cases, and in $73 \%$ of cases the relative CSF-IgG concentration exceeds the upper normal value of $10.0 \%$ of total protein (Link and Muller, 1971). Myelin fragments were initially detected in CSF of 2 patients with MS using electron microscopic techniques (Herndon and Johnson, 1970). Subsequently radioimmunoassays (RIA) were used to detect CSF myelin basic protein (MBP) or fragments of it (McPherson, et al 1972). Cohen et al (1976) using a sensitive radioimmunoassay that could measure as little as $4 \mathrm{ng}$ MBP per ml of CSF studied three clinical categories of MS patients. Nineteen patients whose disease was in remission, had no demonstrable basic protein $(<4 \mathrm{ng} / \mathrm{ml})$. Eleven of 13 whose disease was chronically active - the slowly progressive form of MS - had low levels of MBP (4-16 ng/ml). All 15 patients in acute exacerbations had very high levels of MBP $(>16 \mathrm{ng} / \mathrm{ml}$ ). Although levels of CSF - MBP did correlate with disease activity, neurological details of the acute exacerbations were not provided.

Whitaker (1977) with a double antibody RIA performed on unconcentrated CSF reported that 8 of 14 patients in an acute phase of MS had levels of 3.4 to $15.4 \mathrm{ng} / \mathrm{ml}$ of the $P_{1}$ fragment (residues 43-88) of myelin encephalitogenic protein. This fragment was absent in 29 MS patients who were stable or had gradually progressive disease. Although the concentration of $P_{1}$ fragment was highest in individuals with more severe exacerbations, further neurological details were not provided. In a follow-up report, Whitaker et al (1980) detected 2-200 ng of $P_{1}$ fragment $/ \mathrm{ml}$ of CSF in 23 of $33 \mathrm{MS}$ patients in acute exacerbations of less than 2 weeks duration, and in 71 MS patients who were either stable or who had had an exacerbation of more than 2 weeks duration, only one patient had a marginally elevated level.

Cohen et al (1980) studied 187 CSF samples from MS patients and 22 samples from patients with optic neuritis. Fifty-six of 60 MS patients in acute exacerbation had CSF-MBP levels greater than $8 \mathrm{ng} / \mathrm{ml}, 45$ of 81 patients with the slowly progressive form of the disease had MBP levels between $4-8 \mathrm{ng} / \mathrm{ml}$, and 9 of 22 patients with optic neuritis had detectable MBP in CSF.

MS causes many different neurological syndromes ranging from mild exacerbations affecting one or more areas of the CNS to the rapidly progressive form leading to severe disability within a few months. The purpose of this study was to investigate the levels of CSF-MBP determined by RIA in various syndromes associated with MS. Our subjects included patients with initial attacks affecting the optic nerves or the medial longitudinal fasciculus, patients experiencing acute monosymptomatic or polysymptomatic exacerbations, and patients with chronic progressive neurologic deterioration.

From The Multiple Sclerosis Research Clinic, Department of Medicine (Neurology), University of Alberta and Cross Cancer Institute, Edmonton Received April 14, 1983. Accepted July 22, 1983.

Reprint requests to: Dr. K.G. Warren, 9-101A Clinical Sciences Building, 83rd Avenue at 112 Street, Edmonton, Albertá, Canada T6G 2G3. 


\section{Material and Methods}

CSF-MBP was measured by a previously reported silica gel RIA (Hsuing, et al, 1978).

Sample collection: CSF samples were collected and assayed under blind code from MS patients investigated at the MS Research Clinic, University Hospital, Edmonton, Canada. All the samples were centrifuged to remove cells and stored at $-20^{\circ} \mathrm{C}$ until the RIA was performed. All patients were neurologically classified before the lumbar puncture, and the person performing the RIA (IC) had no knowledge of the clinical details.

CSF from 151 patients with acute lymphoblastic leukemia was obtained to provide a "normal" control value for CSFMBP. The CSF was obtained prior to any therapy being administered to the leukemic children and young adults. CSFMBP values, as well as cell count, TP, relative IgG level, and glucose were determined on 25 patients with acute optic neuritis, 7 patients with acute internuclear ophthalmoplegia, 32 patients with chronic progressive MS, 21 MS patients experiencing monosymptomatic exacerbations and 29 experiencing polysymptomatic exacerbations.

Preparation of Antigen: Myelin basic protein was prepared from normal brain (Diebler, et al 1972) and used after further purification as starting material for radiolabelling as well as for standards and antigen.

Labelling of MBP: The iodination was performed every 3-4 weeks according to a modification (Hsuing, et al 1978) of the chloramine T method of Hunter and Greenwood (1962). Briefly, 5-10 $\mu$ g human MBP were reacted with $\mathrm{NaI}^{125}$ (Edmonton Radiopharmacy) in the presence of chloramine $T$. The reaction was stopped with sodium metabisulfite and the final product was purified on a Sephadex (G25M) column.

Preparation of Antibody: Antibody against human MBP was raised in 6 month old New Zealand white rabbits. The rabbits were initially injected with an emulsion of complete Freund's adjuvant $\left(\mathrm{CF}_{\mathrm{a}}\right)$ and either plain human MBP (Palfreyman, et al. 1978) or a MBP-DNA conjugate (Whitaker, 1975). Boosters with a similar emulsion in incomplete Freund's adjuvant were given every 4 weeks and starting on week 14 the rabbits were bled from the marginal ear vein. To provide sufficient antiserum, the rabbits were boosted every 4-6 weeks and bled one week later. The serum obtained was stored at $-20^{\circ} \mathrm{C}$ and used without further purification.

Radioimmunoassay: The unconcentrated CSF $(0.5 \mathrm{ml})$ was incubated with the antibody in the presence of $30 \%$ normal rabbit serum (NRS) and $10 \%$ concentrated TRIS buffer $\left(10 \mathrm{xT}_{3}\right)$. After 24 hours incubation at $4^{\circ} \mathrm{C}, \mathrm{I}^{125}$ - MBP was added and incubation was continued for 6-18 hours. The reaction was terminated by the addition of silica gel suspension. After centrifugation, the counts were plotted as percentage bound to antibody (\%B) from which the nonspecific binding (NSB) was subtracted (Hsuing et al., 1978).

\section{RESULTS}

A normal range for CSF-MBP was determined by studying CSF from children and young adults with acute lymphoblastic leukemia. These subjects have their CSF-MBP determined before commencing therapy and before every treatment in order to monitor possible demyelination. The CSF-MBP level before any therapy was administered was used to determine normal levels. The mean MBP level of normal CSF so defined was $3.9 \mathrm{ng} \mathrm{MBP} / \mathrm{ml} \mathrm{CSF}$, with a standard deviation (SD) of 1.15. Therefore, utilizing two $S D$, the upper limit of normal was $6.2 \mathrm{ng}$ MBP per $\mathrm{ml}$ of CSF (Figure 1).

Twenty-nine MS patients with polysymptomatic exacerbations had a mean CSF-MBP of $22.3 \mathrm{ng} / \mathrm{ml}$, with a standard deviation of $18.5 \mathrm{ng} / \mathrm{ml}$. This value is significantly different $(\mathrm{p}<0.001)$ from the normal mean. The CSF-MBP levels for $21 \mathrm{MS}$ patients with monosymptomatic exacerbations were also determined. Their mean MBP value was $8.2 \pm 3.4 \mathrm{ng} / \mathrm{ml}$. In 32 patients with chronic progressive disease, the mean MBP level was $6.7 \pm 3.2 \mathrm{ng} / \mathrm{ml}$. These latter groups, as well as patients with acute optic neuritis $(n=25$, mean MBP value $=7.6 \mathrm{ng} / \mathrm{ml}, \mathrm{SD}$ $=2.0)$ and patients with internuclear ophthalmoplegia $(n=7$, mean $\mathrm{MBP}$ value $=6.8 \mathrm{ng} / \mathrm{ml}, \mathrm{SD}=2.03$ ) had significantly different MBP values $(p<0.001)$ from those patients with polysymptomatic exacerbations and the normal group. Patients with polysymptomatic exacerbations have significantly more CSF-MBP than any other MS category including patients with initial exacerbations causing optic neuritis or internuclear ophthalmoplegia, or patients with well established MS experiencing monosymptomatic exacerbations or chronic progression of their disease. None of the MBP levels correlated with CSF total protein value or with gamma globulin levels. The results of the CSF studies for patients and controls are summarized in Tables 1 and 2 .

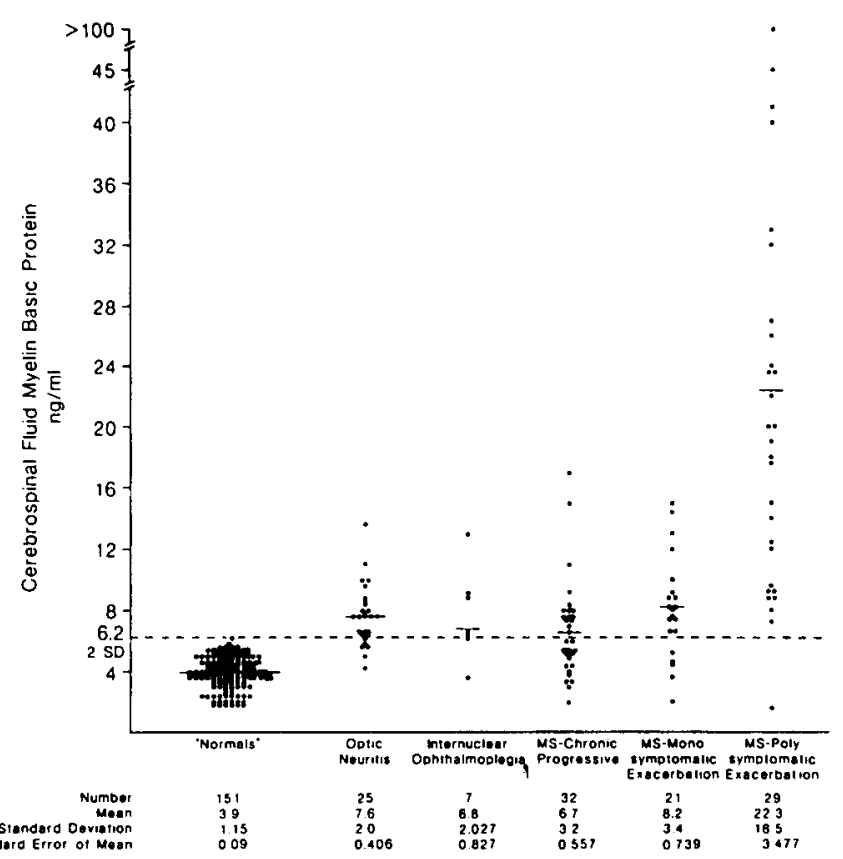

Figure 1-Cerebrospinal fluid myelin basic protein values of "normal"' controls and patients with various demyelinating disease clinical syndromes. 


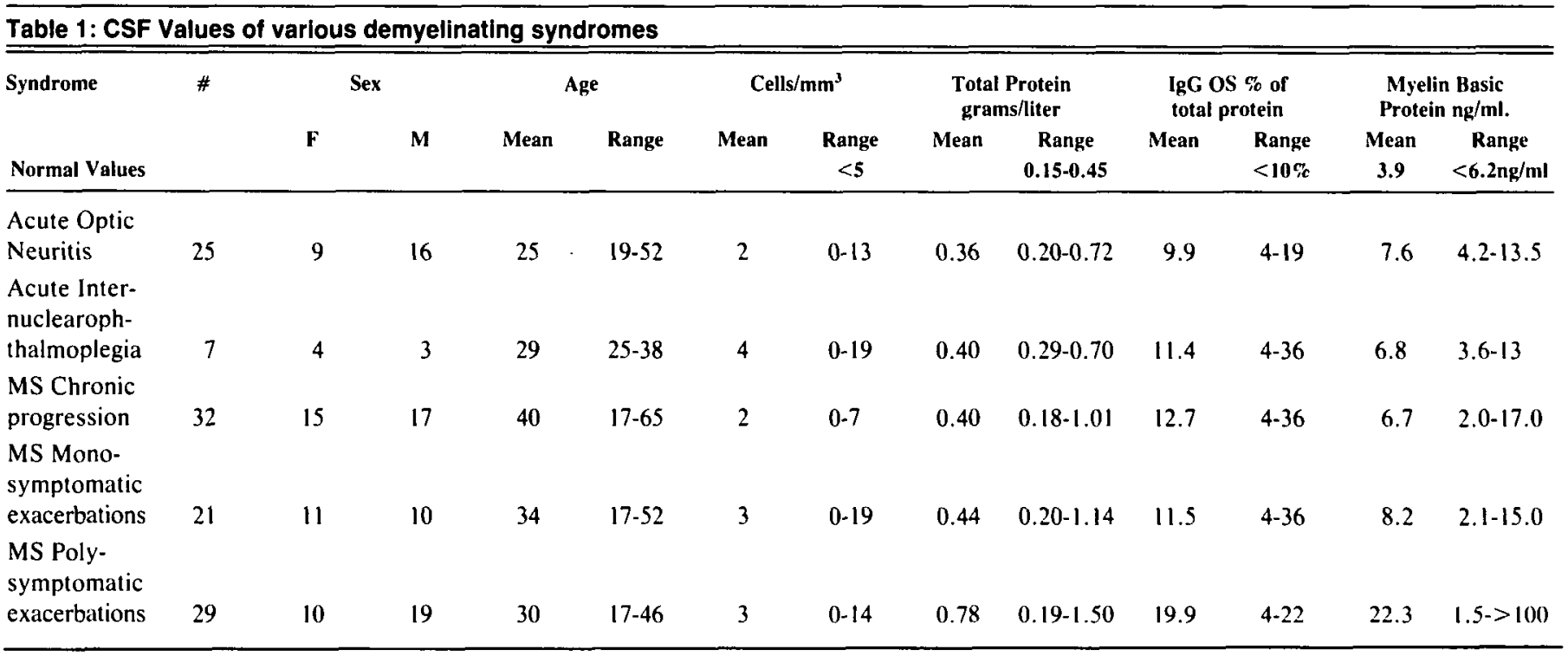

Table 2: Cerebrospinal fluid myelin basic protein levels in control subjects and patlents with various demyelinating syndromes

\begin{tabular}{|c|c|c|c|c|c|}
\hline \multirow[b]{2}{*}{ Patient group } & \multirow[b]{2}{*}{ Number } & \multicolumn{2}{|c|}{$\begin{array}{c}\text { CSF Level of MBP } \\
\text { (ng/ml) }\end{array}$} & \multicolumn{2}{|c|}{$\begin{array}{c}\text { Statistical } \\
\text { Significance* }\end{array}$} \\
\hline & & Mean & SD & T Value & P Value \\
\hline Control & 151 & 3.87 & 1.146 & & \\
\hline Optic Neuritis & 25 & 7.636 & 2.032 & 13.349 & $<0.001$ \\
\hline $\begin{array}{l}\text { Internuclear } \\
\text { Ophthalmoplegia }\end{array}$ & 7 & 6.8 & 2.027 & 6.357 & $<0.001$ \\
\hline $\begin{array}{l}\text { MS - Chronic } \\
\text { Progressive }\end{array}$ & 32 & 6.675 & 3.156 & 8.607 & $<0.001$ \\
\hline $\begin{array}{l}\text { MS - Monosymp- } \\
\text { tomatic } \\
\text { Excerbation }\end{array}$ & 21 & 8.176 & 3.386 & 10.295 & $<0.001$ \\
\hline $\begin{array}{l}\text { MS - Polysymp- } \\
\text { tomatic } \\
\text { Excerbation }\end{array}$ & 28 & 23.057 & 18.40 & 12.838 & $<0.001$ \\
\hline
\end{tabular}

*Student's t-test

Twenty-five of the patients studied had acute optic neuritis, without clinical evidence of disseminated disease. There were 9 males and 16 females with ages ranging from 19-52 (mean age = 25 years). The mean CSF-MBP level was $7.6 \mathrm{ng} / \mathrm{ml}$ (range 4.2-13.5). Nineteen of the 25 patients had CSF-MBP levels above $6.2 \mathrm{ng} / \mathrm{ml}$. Therefore, it can be concluded that a plaque of acute demyelination clinically restricted to one optic nerve will cause an approximate 2 fold increase in CSF-MBP levels in $80 \%$ of patients with acute optic neuritis. All CSF samples collected from patients with acute optic neuritis were obtained within 10 days of the onset of symptoms and before any therapy was administered. In addition to elevated CSF-MBP levels in the majority of patients with acute optic neuritis, the 25 patients in this study showd $0-13$ cells $/ \mathrm{mm}^{3} \mathrm{CSF}$ (mean 2), total protein
$0.20-0.72$ grams/liter (mean 0.36 ), and the $\operatorname{IgG}$ as percent of total protein was 4-19\% (mean 9.9). The mean values for cells, total protein, and relative IgG levels are within normal limits. A normal CSF-MBP level does not negate a clinical diagnosis of acute optic neuritis.

Seven patients, with an age range $25-38$ (mean 29 ) with acute internuclear ophthalmoplegia (4 males and 3 females) were also studied. Like the patients with acute optic neuritis, these patients were experiencing their first attack of probable MS and at the time of the study did not have neurological disease disseminated in time and place. All of these patients had other potential causes of internuclear ophthalmoplegia excluded, and they had recovered when reassessed weeks to months later. The CSF was obtained during the acute phase of the illness and prior to any potential therapy such as steroid medication. CSF-MBP level in these 7 patients was $3.6-13.0 \mathrm{ng} / \mathrm{ml} \mathrm{CSF}$ with a mean of $6.8 \mathrm{ng} / \mathrm{ml}$. The mean level was increased above normal values. Five of the 7 patients had CSF-MBP levels above $6.2 \mathrm{ng} / \mathrm{ml}$. The CSF of these patients with acute internuclear ophthalmoplegia also contained $0-19$ cells $/ \mathrm{mm}^{3}$ (mean 4$), 0.29-0.70 \mathrm{grams} /$ liter of total protein (mean 0.43 ), with $4-36 \%$ IgG (mean 11.4) of total protein. The mean values for cells and total protein are normal, but the mean percent IgG is increased above the normal value of $10 \%$ or less of total protein being $\mathrm{lgG}$. The results of patients with either acute optic neuritis or acute internuclear ophthalmoplegia were similar and demonstrate that acute demyelination restricted to one neuroanatomical locus may cause a modest but significant elevation of CSF-MBP.

Clinically definite MS patients were also studied. Thirty-two MS patients whose disease was progressing year by year had CSF-MBP levels of $2.0-17.0 \mathrm{ng} / \mathrm{ml}$ (mean 6.7). The mean value of $6.7 \mathrm{ng} / \mathrm{ml}$ was significantly increased above normal. There were 15 males and 17 females, age range $17-65$ (mean 40 years) in this part of the study. Fifteen of the 32 patients had CSFMBP levels more than 2 standard deviations above the normal mean. Thus approximately $50 \%$ of MS patients in the chronic progressive phase of their disease can be expected to have increased CSF-MBP levels. The level of CSF-MBP in these patients is probably a reflection of the amount of demyelination 
that is occurring on a day to day basis. As would be expected these patients with clinically definite MS had an increased relative $\mathrm{IgG}$ concentration with a mean of $12.7 \%$ (range $4-36 \%$ ) of total protein. CSF cells and total protein levels were frequently normal with the cell count being $0-7$ (mean 2)/ $/ \mathrm{mm}^{3}$, and the total protein level was 0.18-1.01 (mean 0.40) grams/liter. The rate of progression of MS is variable. Longitudinal analysis is required to determine whether CSF-MBP levels correlate with the rate of clinical deterioration.

To determine the quantitative value of CSF-MBP levels determined by RIA, clinically definite MS patients with acute exacerbations were divided into two groups. Patients with sensory, motor, or cerebellar monosymptomatic exacerbations, reflecting less extensive demyelination, were compared with patients experiencing polysymptomatic exacerbations who were postulated to have quantitatively more myelin destroyed. These two groups were comparable with respect to age, sex, and time from onset of symptoms to performance of the lumbar puncture. There were 21 patients with monosymptomatic exacerbations, 11 males and 10 females, age range $17-52$ years (mean 34); and 29 patients with polysymptomatic exacerbations, 10 males and 19 females, age range $17-46$ years (mean 30 ). Monosymptomatic exacerbations were associated with a CSF-MBP level of $8.2 \mathrm{ng} / \mathrm{ml}$ (range 2.1-15.0) whereas polysymptomatic exacerbations were associated with higher CSF-MBP levels with a mean of $22.3 \mathrm{ng} / \mathrm{ml}$ (range 1.5->100). Sixteen of the 21 patients $(76 \%)$ with monosymptomatic exacerbations and 28 of 29 patients (96\%) with polysymptomatic exacerbations had CSF-MBP levels greater than 2 SD above the normal mean. MS patients with polysymptomatic exacerbations not only had significantly more CSF-MBP than normal controls, but also had significantly more CSF-MBP than MS patients with monosymptomatic exacerbations, MS patients with chronic progressive disease, or patients with either acute optic neuritis or acute internuclear ophthalmoplegia. As predicted, the CSF-MBP level is a direct indication of the amount of demyelination that is occurring at or closely around the time the CSF sample is obtained. Patients with monosymptomatic and polysymptomatic exacerbations had similar cell counts at 0-19 (mean 3 ) and 0-14 (mean 3 ) respectively. Total CSF protein levels were higher in MS patients with polysymptomatic exacerbations than in those with monosymptomatic exacerbations. MS monosymptomatic exacerbations were associated with 0.20-1.14 grams/liter (mean 0.44) whereas polysymptomatic exacerbations were associated with 0.19-1.50 grams/liter (mean 0.78). Relative IgG levels were $11.5 \%$ (range 4-36) in MS patients with monosymptomatic exacerbations, and in those with polysymptomatic exacerbations the relative IgG was $10.9 \%$ (range $4-22$ ).

Cerebrospinal fluid MBP levels are an indication of the quantity of demyelination in MS patients, and its quantitation could be used to monitor disease activity and to study the effect of putative therapies. CSF-MBP levels may also be of value in the diagnosis of MS. For example, if a young patient has many acute neurological symptons and apparent physical handicaps but has normal CSF-MBP levels then the patient is unlikely to have MS but may have another neurological or psychiatric disease. Malignant and persistantly active forms of MS produce consistently high CSF-MBP levels when studied over weeks and months (Warren et al., 1982). Although the assay used in this study was useful as a marker of demyelination, because silica gel is a nonspecific precipitant and because of the high protein concentration ( $30 \%$ NRS) the nonspecific binding was relatively high (20-30\%), the sensitivity was not as good as we wished and the MBP levels detected in "normal" subjects were up to $6.2 \mathrm{ng} / \mathrm{ml}$. Therefore, we have now developed a more rapid, more sensitive, and more accurate double antibody assay for quantitation of MBP in CSF.

\section{ACKNOWLEDGEMENTS}

This research project was supported by the Multiple Sclerosis Society of Canada, and Friends of Multiple Sclerosis Research of Edmonton Canada. The authors are grateful for Drs. D.J. Carroll, H. Jacobs, G. Monckton, D. McLean, T.A.S. Boyd, R. Morgan, W. Pearce, K. Shutt, S. Leong-Sit, and $\mathrm{H}$. Wyatt for providing clinical assistance with this research project. Ms. Verona Jeffrey provided excellent technical support.

\section{REFERENCES}

Cohen, S.R., Brooks, B.R., Herndon, R.M. and McKhann, G.M. (1980). A diagnostic index of active demyelination: Myelin basic protein in cerebrospinal fluid. Annals Neurol. 8(1) 25-31.

Cohen, S.R., Herndon, R.M. and McKhann, G.M. (1976). Radioimmunoassay of myelin basic protein in spinal fluid. New Engl. J. Med. 295(26) 1455-1457.

Diebler, G.E., Marteuson, R.E. and Kies, M.W. (1972). Large scale preparation of myelin basic protein from central nervous tissue of several mammalian species. Prepr. Biochem 2: 139-165.

Herndon, R.M. and Johnson, M. (1970). A method for the electron microscopic study of cerebrospinal fluid sediment. J. Neuropathol Exp. Neurol. 29: 320-330.

Hsuing, H.M., Wu, J. and McPherson, T.A. (1978). Silica gel radioimmunoassay for myelin basic protein. Clin. Biochem., $1 /(2): 54-56$.

Hunter, W.M. and Greenwood, F.C. (1962). Preparation of $1^{131}$ labelled human growth hormone of high specific gravity. Nature 195:495.

Link, H. and Muller, R. (1971). Immunoglobulins in Multiple Sclerosis and Infections of the nervous system. Arch. Neurol. 25: 326-344.

McPherson, T.A., Gilpin, A. and Seland, T.P. (1972). Radioimmunoassay of cerebrospinal fluid for encephalitogenic basic protein: A diagnostic test for MS $\pi$ Can. Med. Assn. J. 101, 856-859.

Palfreyman, J.W., Thomas, G.T. and Ratcliffe, J.G. (1978). Radioimmunoassay of human myelin basic protein in tissue extract, cerebrospinal fluid and serum and its clinical application to patients with head injury. Clin. Chim. Acta. 82:259.

Warren, K.G., Gordon, P.A. and McPherson, T.A. (1982). Plasma exchange of malignant multiple sclerosis. Can. J. Neurol. Sci. 9(1) 27-30.

Whitaker, J.N. (1975). The antigenicity of myelin basic protein: production of antibodies to encephalitogenic protein with DNA - encephalitogenic protein complexes. J. Immunol. 114(2) 823-000.

Whitaker, J.N. (1977). Myelin encephalitogenic protein fragments in cerebrospinal fluid of persons with Multiple Sclerosis. Neurology 27:911-920.

Whitaker, J.N., et al. (1980). Immunoreactive myelin basic protein in the cerebrospinal fluid in neurological disorders. Annals Neurol. $7(1)$. 